\title{
Demand for Charter Boat Fishing in the Northeast Region of Taiwan
}

\section{David S. Liao}

Institute of Fisheries Economics National Taiwan Ocean University Keelung, Taiwan, R. O. C.

Follow this and additional works at: https://jmstt.ntou.edu.tw/journal

Part of the Aquaculture and Fisheries Commons

\section{Recommended Citation}

Liao, David S. (1995) "Demand for Charter Boat Fishing in the Northeast Region of Taiwan," Journal of Marine Science and Technology. Vol. 3: Iss. 1, Article 1.

DOI: 10.51400/2709-6998.2499

Available at: https://jmstt.ntou.edu.tw/journal/vol3/iss1/1

This Research Article is brought to you for free and open access by Journal of Marine Science and Technology. It has been accepted for inclusion in Journal of Marine Science and Technology by an authorized editor of Journal of Marine Science and Technology. 


\title{
DEMAND FOR CHARTER BOAT FISHING IN THE NORTHEAST REGION OF TAIWAN
}

\author{
David S. Liao \\ Institute of Fisheries Economics \\ National Taiwan Ocean University \\ Keelung, Taiwan, $R$. O. C.
}

Key words: charter boat fishing, demand model.

\begin{abstract}
The determinants of demand for charter boat fishing were examined using a travel cost demand model. Catch rate, trip costs, fishing experience, and income significantly affect charter boat fishing. Thus, the improvement of catch rate and trip costs could be a desirable policy for the charter boat industry in Taiwan.
\end{abstract}

\section{INTRODUCTION}

Charter boat fishing is unique because it combines elements of commercial fishing (the charter boat operation is a business) as well as recreational fishing (the customer is sport fishermen). Charter boat operators provide access to fishing areas for their customers who can not purchase boats and fishing equipment or prefer to let others purchase such equipment. Basically, charter boat businesses are suppliers of services demanded by sport fishermen and rely on the availability of a publicly owned resource, fish stock, as one of the inputs in the production of services. Thus, fish stocks are important for charter boat fishing.

Charter boat fishing has become a popular outdoor activity in Taiwan. During 1993, a total of ninety charter boats were identified as being in business in the Northeast region (Liao and Huang, 1995). Increased participation in recreational fishing has created problems for fishery management. Assessing the demands of recreational and commercial fishing on fisheries resources is one of the most difficult tasks confronting fisheries managers. Historically, emphasis has been placed on the commercial harvest of fisheries resources. As a result, much of the available data concerning the biological and economic impacts of fisheries utilization pertain to commercial fishing industries. Thus, there is a very little information available relating to demand aspects of recreational fishing.

The purpose of this paper is to provide some

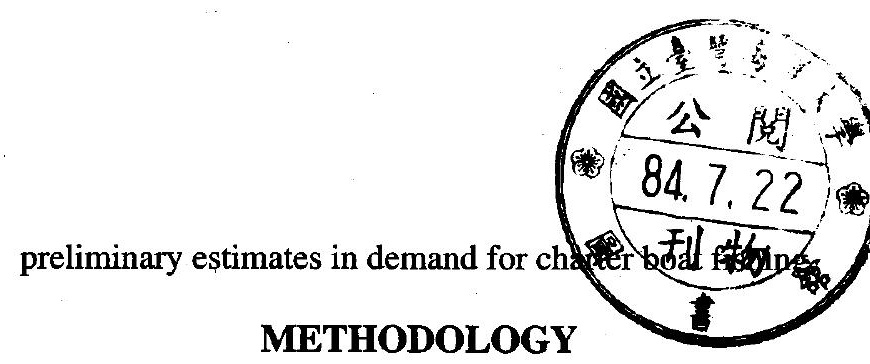

The survey of charter boat operators was conducted using the personal interview method to collect data. All charter boat operators in Taipei county, Keelung city, and Ilan county in 1993 constituted the "population" for the survey. Sample size and population for each location are shown in Table 1 . As indicated, 44 out of 90 operators $(48.9 \%)$ were interviewed. A survey form was pretested and then employed by the interviewers.

Data from the charter boat customers was also obtained through personal interviews. A sample of anglers to be interviewed were randomly chosen from charter boat operators' 1993 log books. The log books were used by the operators to record their customers' trip reservation. Operators who had kept log books were requested to provide a list of their customers names and telephone numbers. Eighty-three fishermen were drawn from the $\log$ books and were interviewed for the survey.

The survey data from charter boat operators were analyzed to estimate the total fishing trips taken in 1993. The survey data from charter boat anglers were used in conducting the empirical demand model estimation by the statistical procedures of least square regression. This analysis permitted the examination of several factors that appear related to the number of fishing trips 
taken by sport fishermen.

\section{FINDINGS}

\section{Estimation of Fishing Trips and Fishermen}

Generally, the charter boats in northeastern Taiwan operate year round (Tale 2). In 1993, the charter boats in Taipei county and Keelung city averaged 162 fishing trips annually while those in Ilan county had 159 fishing trips per year. Thus, it appears that there was no marked difference in the annual fishing trips between two geographical areas. However, it should be pointed out that during the winter the charter boats in Taipei county and Keelung city had fewer fishing trips than those in Ilan county. This was due to the quite severe weather in Taipei county and Keelung city during the winter. Recreational fishing in severe weather can be difficult since the vessel's motion can make passengers uncomfortable. Data on the average number of fishing trips per boat were extrapolated to obtain the estimated total number of fishing trips by all charter boat fishermen in the Northeast region. It was estimated that the total number of fishing trips was 14,535 (Table 3 ).

The total number of charter boat fishermen by location was also estimated (Table 4). There were 108,083 charter boat anglers who fished in the coastal waters of Taipei county and Keelung city during the study period. This accounted for $81 \%$ of the total number of charter boat anglers $(133,224)$. A total of 25,141 anglers used charter boats in Ilan county for their offshore fishing trips.

\section{Estimation of Demand model for Charter Boat Fishing}

Traditional demand theory analyzes consumption

Table 1. Survey of charter boat operators in the Northeast Region of Taiwan

\begin{tabular}{|cccccc|}
\hline \multirow{5}{*}{ Population } & $\begin{array}{c}\text { Type of } \\
\text { Boat }\end{array}$ & $\begin{array}{c}\text { Keelung } \\
\text { City }\end{array}$ & $\begin{array}{c}\text { Taipei } \\
\text { County }\end{array}$ & $\begin{array}{c}\text { Ilan } \\
\text { County }\end{array}$ & Total \\
& Full time & 1 & 4 & 0 & 5 \\
& Part time & 8 & 57 & 20 & 85 \\
& Total (1) & 9 & 61 & 20 & 90 \\
\hline Sample & Full time & 1 & 4 & 0 & 5 \\
& Part time & 2 & 23 & 14 & 39 \\
& Total (2) & 3 & 27 & 14 & 44 \\
\hline Sample size & $(2) /(1)$ & $33.3 \%$ & $44.3 \%$ & $70 \%$ & $48.9 \%$ \\
\hline
\end{tabular}

Table 2. Average fishing trips of charter boats in 1993.

\begin{tabular}{lccr}
\hline \multicolumn{1}{c}{$\begin{array}{c}\text { ITEM } \\
\text { Total Annual Fishing Trips }\end{array}$} & $\begin{array}{c}\text { Taipei County } \\
\text { and Keelung City }\end{array}$ & Ilan County & Total \\
\hline $\begin{array}{l}\text { Monthly distribution of } \\
\text { fishing trips: }\end{array}$ & 162.36 & 158.52 & 161.13 \\
January & 5.30 & 7.40 & 5.97 \\
February & 5.30 & 8.50 & 6.32 \\
March & 11.00 & 10.02 & 10.69 \\
April & 18.80 & 16.60 & 18.10 \\
May & 18.00 & 15.80 & 17.30 \\
June & 19.00 & 16.60 & 18.24 \\
July & 20.00 & 17.80 & 19.30 \\
August & 18.73 & 17.50 & 18.34 \\
September & 18.63 & 16.00 & 17.79 \\
October & 14.42 & 13.00 & 14.42 \\
November & 7.00 & 10.50 & 8.11 \\
December & 5.80 & 8.80 & 6.73 \\
\hline
\end{tabular}


Table 3. Estimated total number of fishing trips of charter boats in 1993.

\begin{tabular}{lcccc}
\hline Type of boat & $\begin{array}{c}\text { Number of Trip } \\
\text { Per boat }\end{array}$ & $\begin{array}{c}\times \\
\text { Number of Charter } \\
\text { boats }\end{array}$ & $\begin{array}{c}\text { Total Number } \\
\text { of Fishing trips }\end{array}$ \\
\hline $\begin{array}{l}\text { Taipei County } \\
\text { \& keelung City }\end{array}$ & 162.36 & 70 & 11365.20 \\
$\begin{array}{l}\text { Ilan County } \\
\text { Total }\end{array}$ & 158.52 & 20 & 3170.40
\end{tabular}

14535.60

Table 4. Etimated number of anglers chartered by charter boats

\begin{tabular}{lccccc}
\hline Type of boat & $\begin{array}{c}\text { Number of } \\
\text { anglers chartered } \\
\text { per trip }\end{array}$ & $\begin{array}{c}\times \\
\text { Number of } \\
\text { Trips per } \\
\text { boat }\end{array}$ & $\begin{array}{c}\text { Number of } \\
\text { charter } \\
\text { boats }\end{array}$ & $\begin{array}{c}\text { Total number } \\
\text { of anglers } \\
\text { chartered }\end{array}$ \\
\hline $\begin{array}{l}\text { Taipei County } \\
\text { \& keelung City }\end{array}$ & 9.51 & 162.36 & 70 & $108,083.05$ \\
$\begin{array}{l}\text { Ilan County } \\
\text { Total }\end{array}$ & 7.93 & 158.52 & 20 & $25,141.27$ \\
\hline
\end{tabular}

decisions within a context of constrained optimization. The objective is to maximize utility(satisfaction) by selecting the optimal bundle of goods and services subject to a given set of constraints. In our case, the utility function is simplified to represent charter boat trips to northeastern Taiwan, subject to an income constraint and a time constraint.

\section{$\operatorname{Max} U(C: R)$}

subject to $\mathrm{Y}=\mathrm{Pc} * \mathrm{C}+\mathrm{Pr} * \mathrm{R}$ (budget constraint) $\mathrm{T}=\mathrm{Tc}{ }^{*} \mathrm{C}+\mathrm{Tr}{ }^{*} \mathrm{R}+\mathrm{Tw}$ (time constraint)

$\mathrm{U}=$ utility

$\mathrm{C}=$ charter boat fishing trips

$\mathrm{R}=$ vector of fishing related substitute and complementary goods and services

$\mathrm{Y}=$ Income

$\mathrm{Pc}=$ price of charter boat fishing trips

$\mathrm{Pr}=$ vector of prices for fishing related substitutes and complements.

$\mathrm{T}=$ total time available

$\mathrm{Tc}=$ time required to pursue the charter boat trips

$\mathrm{Tr}=$ time required to pursue other fishing related activities

$\mathrm{Tw}=$ time at work

As suggested in demand theory, the variables normally utilized in recreational demand functions fall into five general categories: price, time, quality, substitutes and socioeconomics. Thus, an empirical demand model for charter boat fishing is specified as follows:

TRIPS $=\mathrm{B}_{0}+\mathrm{B}_{1} \mathrm{EXP}+\mathrm{B}_{2} \mathrm{CAT}+\mathrm{B}_{3} \mathrm{INC}+\mathrm{B}_{4} \mathrm{TTC}+\mathrm{B}_{5}$ $\mathrm{OTC}+\mathrm{B}_{6} \mathrm{CAR}+\mathrm{B}_{7} \mathrm{OC} 1+\mathrm{B}_{8} \mathrm{OC}_{2}+\mathrm{B}_{9} \mathrm{OC}_{3}$ $+\mathrm{B}_{10} \mathrm{OC}_{4}+\mathrm{B}_{11} \mathrm{EDU}+\mathrm{e}$

Where TRIPS = number of charter boat fishing trips taken by anglers

EXP = the number of years of charter boat fishing experience;

$\mathrm{CAT}=$ fish catch per trip;

INC = the estimated annual income;

TTC $=$ total trip costs including travel costs, charter fees, and time costs;

$\mathrm{OTC}=$ total costs for other types of fishing trips;

$\mathrm{CAR}=$ car ownership $(1=$ if car owner, $0=$ otherwise);

$\mathrm{OC}_{1}=1$, if employed in the manufacture sector 0 , otherwise;

$\mathrm{OC}_{2}=1$, if employed in the construction sector 0 , otherwise;

$\mathrm{OC}_{3}=1$, if employed in the sale sector 0 , otherwise;

$\mathrm{OC}_{4}=1$, if employed in the other sector 0 , otherwise;

$\mathrm{EDU}=$ educational level (1=none, 2=primary school, 3=secondary school, 4=high school, $5=$ college or higher);

$\mathrm{e}=\quad$ the random error term; 
$\mathrm{B}_{0}, \mathrm{~B}_{1}, \mathrm{~B}_{2}, \mathrm{~B}_{3}, \mathrm{~B}_{4}, \mathrm{~B}_{5}, \mathrm{~B}_{6}, \mathrm{~B}_{7}, \mathrm{~B}_{8}, \mathrm{~B}_{9}, \mathrm{~B}_{10}, \mathrm{~B}_{11}$ are regression parameters and to be estimated.

Based on the survey data, the above model was estimated by using ordinary least-squares method. The results are shown in Table 5. Years of charter boat

Table 5. Estimated Demand Function for Charter Boat Recreational Fishing

\begin{tabular}{lrrc}
\hline $\begin{array}{l}\text { Independent } \\
\text { Variable }\end{array}$ & Coefficients & t-Value & $\begin{array}{c}\text { Significant } \\
\text { level }\end{array}$ \\
\hline Constant & 49.587528 & 1.927 & 0.0579 \\
EXP & 2.902269 & 3.497 & 0.0008 \\
CAT & 0.351627 & 2.047 & 0.0444 \\
INC & 0.000066 & 2.861 & 0.0055 \\
TTC & -0.003624 & -1.788 & 0.0780 \\
OTC & 0.008607 & 1.124 & 0.2649 \\
CAR & 6.063738 & 0.403 & 0.6879 \\
OC1 & -37.627613 & -1.892 & 0.0625 \\
OC2 & -37.739311 & -1.859 & 0.0671 \\
OC3 & -24.600449 & -1.183 & 0.2407 \\
OC4 & -26.895876 & -1.421 & 0.1597 \\
EDU & -6.454023 & -1.894 & 0.0623 \\
\hline $\mathrm{R}^{2}=0.447$ & & &
\end{tabular}

fishing experience by the anglers have a significant effect on the number of trips taken. Catch per trip is statistically significant which is consistent with economic theory and previous studies and suggests that catch rate should be an important determinant of the demand for charter recreational fishing. Fishermen are responsive to changes in fishing success. The coefficient of income is statistically significant and has the positive sign. This indicates that increases in income have virtually positive effect on fishing trip demand. The total trip cost variable accounts for both the trip costs and time costs. Time cost is a measure of the opportunity cost of time in terms of lost wages. In the estimated equation, the expected relationship between the number of trips and total trip coats is seen. The estimated coefficient of trip cost is significant and negative. An addition increase in cost of trips results in a decrease in the number of trips. The estimates of education variable suggest that higher education does not constitute to an increase in the number trips.

\section{CONCLUSIONS}

This analysis incorporated socioeconomic and quality variables in the travel cost demand model to determine their influence on fishermen's decisions about charter boat fishing in the Northeast Region of Taiwan. Catch rate, fishing experience and income level are found to significantly affect the demand for charter boat fishing. Trip costs have a negative impact upon additional fishing trips.

Estimated total charter boat fishing trips in the Northeast region in 1993 were 14,535. It appears that the use of fishery resources for outdoor recreation is growing in Taiwan. Management of fishery resources requires better knowledge of the determinants of recreation demand. In order to gain this knowledge, improved modeling methods and better data are needed. Recreation demand models, such as the travel cost model, provide a useful method for analyzing recreation demand determinants, as demonstrated in this paper.

\section{REFERENCES}

1. Bockstael, Nancy E., I.E. Strand, and W.M. Hanemann. 1987. Time and the Recreational Demand Model. Amer. J. Agr. Econ., 69: 293-302.

2. Gum, R.L. and W.E. Martin. 1977. Structure of Demand for Outdoor Recreation. Land Econ. 53: 43-55.

3. Liao, David S. and Tsung-Hsi Huang. 1995. An Economic Analysis of the Charter Boat Recreational Fishing Industry in the Northeast Region of Taiwan. Proceedings of the 7th Biennal International Conference of the International Institute of Fisheries Economics and Trade, Taipei, R. O. C. , July 18-21, 1994.

4. McConnell, Kenneth E. 1975. Some Problems in Estimating the Demand for Outdoor Recreation. Amer. J. Agr. Econ., 57: 330-334.

5. McConnell, Kenneth E and Ivar E. Strand. 1981. Measuring the Cost of Time in Recreational Demand Analysis: An Application to Sportfishing. Amer. J. Ag. Econ. 63: 153-156.

6. Smith, V.K., W.H. Desvousges, and M.P. McGivney. 1983. The Opportunity Cost of Travel Time in Recreation Demand Models. Land Econ. 59: 259-277.

7. Ziemer. R.F., W.N. Musser, and R.C. Hill. 1980. Recreation Demand Equations: Functional Form and Consumer Surplus. Amer. J. Agr. Econ., 62: 136-141. 